\title{
Fatal haemorrhage following liver biopsy in patients with HIV infection
} Duncan R Churchill, Darren Mann, Richard J Coker, Robert F Miller, Geoffrey Glazer,
Robert D Goldin, Sebastian B Lucas, Jonathan N Weber, Kevin M De Cock

A retrospective review of all 248 liver biopsies performed in patients with HIV infection at two referral centres in London over a 12 year period revealed five cases of major bleeding following biopsy, with four deaths. The risk of major bleeding was $2 \cdot 0 \%$, and mortality was $1.6 \%$ following liver biopsy. The risk of bleeding was much higher than in published series of biopsies done in patients without HIV infection, owing in part to the high prevalence of thrombocytopaenia and clotting abnormalities in patients with HIV infection. HIV infection per se may also increase the risk of bleeding following liver biopsy.

(Genitourin Med 1996;72:62-64)

Keywords: HIV; liver biopsy; haemorrhage

\section{Introduction}

Percutaneous biopsy of the liver is a wellestablished technique, complicated by significant bleeding in one in every 200-300 patients. ${ }^{12}$ Recently, several case reports have suggested that patients who are HIV-infected may be more likely to bleed following liver biopsy. ${ }^{34}$ A retrospective review at two HIV units in London revealed five cases of major bleeding, of which four were fatal, following liver biopsy in 248 patients with HIV infection.

Department of Genitourinary Medicinel

Communicable

Diseases

D R Churchill

R J Coker

J N Weber

Department of

Surgery

D Mann

G Glazer

Department of

Histopathology, St

Mary's Hospital and

Medical School, Praed

St, London W2 1NY

R D Goldin

Inpatient Unit for

HIVIAIDS, Camden

and Islington

Community Health

Services Trust,

Middlesex Hospital

Site, Mortimer St,

London W1N 8AA

R F Miller

$\mathrm{K} M$ De Cock

Department of

Histopathology,

University College

London Medical

School, London

WC1E 6JJ

$S$ B Lucas

Correspondence to:

Dr Kevin M De Cock,

Department of Clinical

Sciences, London School of

Hygiene and Tropical

Medicine, Keppel St,

London WCIE 7HT, UK.

Accepted for publication

27 November 1995

\section{Case report}

A 41 year old homosexual man (Patient 1; table 1) was admitted to hospital for investigation of an unexplained fever and sweats which had persisted for 3 months. He had been found to be HIV-1 antibody positive 2 years previously, and subsequently had had oral candidiasis, recurrent genital herpes simplex infection, and anogenital warts. He gave a history of fully-treated syphilis and asymptomatic hepatitis B infection (with persistently negative tests for both surface antigen and e antigen). Four years before admission, he had received a standard six month course of triple therapy for a clinical diagnosis of pleural/pulmonary tuberculosis. He was taking co-trimoxazole $960 \mathrm{mg}$ daily as primary prophylaxis against Pneumocystis carinii pneumonia, and isoniazid $300 \mathrm{mg}$ daily as secondary prophylaxis against tuberculosis. His CD4 lymphocyte count was $120 \times 10^{6} / 1(12 \%$; normal range 350-2200 $\left.\times 10^{6} / 1\right)$. Clinical examination revealed hepatosplenomegaly, and a fever of up to $40^{\circ} \mathrm{C}$. Investigations including culture of urine, stool, bone marrow aspirate and multiple peripheral blood samples; serology for Brucella, Coxiella, Histoplasma capsulatum, Cryptococcus neoformans and Entamoeba histolytica; blood films for malaria; an autoantibody profile; a chest radiograph, intravenous pyelogram, abdominal ultrasound scan and abdominal computed tomography (CT) scan all failed to identify the cause of fever. During the course of his investigation progressive abnormalities of liver function tests were noted, with an alkaline phosphatase enzyme level rising to over 5 times the upper limit of normal; bilirubin and transaminase enzymes remained normal. Thrombocytopaenia also developed, with the platelet count falling to $32 \times 10^{9} / 1$, before spontaneously rising over ten days to $64 \times 10^{9} / 1$. In view of the abnormal liver function tests and history of tuberculosis, a granulomatous hepatitis was suspected, and a liver biopsy was planned. Because of thrombocytopaenia and a mildly prolonged prothrombin time (15 seconds; control 12 seconds), and after review by a consultant 
Table 1 Details of patients with bleeding following liver biopsy (FFP $=$ Fresh frozen plasma).

\begin{tabular}{|c|c|c|c|c|c|c|c|c|c|c|c|c|}
\hline $\begin{array}{l}\text { Patient } \\
\text { No }\end{array}$ & $\begin{array}{l}\text { Age } \\
\text { (years) }\end{array}$ & Sex & $\begin{array}{l}\text { Prior } \\
\text { AIDS }\end{array}$ & $\begin{array}{l}\text { CD4+ } \\
\text { count } \\
\left(\times 10^{6} / \mathrm{l}\right)\end{array}$ & $\begin{array}{l}P T \\
(s)\end{array}$ & $\begin{array}{l}H b \\
(g / l)\end{array}$ & $\begin{array}{l}\text { Platelets } \\
\left(\times 10^{9} / \mathrm{l}\right)\end{array}$ & Needle type & Histology & Surgery & Outcome & Notes \\
\hline 1 & 41 & M & No & 120 & 15 & 94 & $\begin{array}{l}64 \\
\text { (increased to } \\
104 \text { after } \\
\text { transfusion) }\end{array}$ & $\begin{array}{l}\text { Biopty gun } \\
\text { Ultrasound } \\
\text { guidance }\end{array}$ & $\begin{array}{l}\text { Non-specific } \\
\text { hepatitis }\end{array}$ & $\begin{array}{l}\text { Laparotomy } \\
16 \text { hours }\end{array}$ & $\begin{array}{l}\text { Died } \\
20 \text { hours }\end{array}$ & $\begin{array}{l}\text { Vitamin K; } \\
4 \text { units platelets, } \\
4 \text { units FFP } \\
\text { before biopsy }\end{array}$ \\
\hline 2 & 36 & $\mathbf{M}$ & No & 420 & 19 & 83 & 80 & Menghini & $\begin{array}{l}\text { Non-specific } \\
\text { hepatitis }\end{array}$ & $\begin{array}{l}\text { Failed } \\
\text { embolisation; } \\
\text { laparotomy }\end{array}$ & $\begin{array}{l}\text { Died } \\
24 \text { hours }\end{array}$ & $\begin{array}{l}\text { Vitamin } \mathrm{K} ; \\
6 \text { units platelets } \\
\text { pre biopsy }\end{array}$ \\
\hline 3 & 46 & $\mathbf{M}$ & Yes & N/A & $14 \cdot 4$ & 111 & 26 & $\begin{array}{l}\text { Temno; } \\
\text { Ultrasound } \\
\text { guidance }\end{array}$ & $\begin{array}{l}\text { Drug-related } \\
\text { hepatitis }\end{array}$ & $\begin{array}{l}\text { Laparotomy } \\
24 \text { hours }\end{array}$ & Survived & $\begin{array}{l}6 \text { units platelets } \\
\text { pre biopsy }\end{array}$ \\
\hline 4 & 30 & $\mathbf{M}$ & Yes & N/A & $16 \cdot 7$ & 103 & 154 & Tru-cut & $\begin{array}{l}\text { Non-specific } \\
\text { hepatitis }\end{array}$ & $\begin{array}{l}\text { Laparotomy } \\
36 \text { hours }\end{array}$ & $\begin{array}{l}\text { Died } \\
48 \text { hours }\end{array}$ & \\
\hline 5 & 40 & $\mathbf{F}$ & Yes & 16 & 13 & 81 & 184 & Tru-cut & Histoplasmosis & None & $\begin{array}{l}\text { Died } \\
5 \text { hours }\end{array}$ & \\
\hline
\end{tabular}

Table 2 Final histological diagnoses following liver biopsy in 248 patients (NB fifteen patients had two diagnoses)

\begin{tabular}{lr}
\hline Viral infection & \\
Chronic Hepatitis B & 86 \\
Chronic Hepatitis C & 37 \\
Cytomegalovirus & 5 \\
Bacterial infection & \\
Mycobacterium avium-intracellulare & 30 \\
Mycobacterium tuberculosis & 8 \\
Protozoal infection & \\
Leishmania sp & 5 \\
Pneumocystis carinii & 3 \\
Microsporidium sp & 1 \\
Fungal infection & \\
Histoplasma capsulatum & 4 \\
Cryptococcus neoformans & 3 \\
Penicillium marneffei & 1 \\
Unidentified fungus & 1 \\
Malignancy & \\
Non-Hodgkin's lymphoma & 8 \\
Hepatocellular carcinoma & 1 \\
Drug reaction/Non-specific hepatitis & 27 \\
Miscellaneous & \\
Biliary obstruction & \\
Peliosis hepatis & \\
Alcoholic hepatitis & \\
Fatty liver & 263 \\
No diagnosis/normal & 1 \\
Total & 1 \\
\hline
\end{tabular}

we have encountered four other cases of major bleeding (defined as bleeding requiring blood transfusion plus surgery/embolisation if clinically appropriate) following liver biopsy (table 1).

\section{Discussion}

Percutaneous biopsy of the liver in carefully selected patients results in serious haemorrhage in one patient in every $200-300$ procedures. Liver biopsy was associated with mortality of between $0.01 \%$ and $0.11 \%$ in several large series. ${ }^{1}$ In contrast to these figures, we encountered a rate of major haemorrhage of $2.0 \%$ and a mortality of $1.6 \%$ from liver biopsies in patients with HIV infection. Formal statistical comparison of complications between such heterogeneous groups is impossible, but the possibility is raised of an increased risk of complications of liver biopsy in patients with HIV infection.

Indications for liver biopsy in patients with HIV infection are numerous, and include the investigation of fever, hepatomegaly, abnormal liver function tests or of focal lesions demonstrated on imaging studies. The majority of biopsies performed for these indications show abnormalities. ${ }^{5}$ Of the 248 biopsies performed for a variety of indications at our units (table 2 ), $70 / 222(31.5 \%)$ revealed major opportunistic infections or tumours, whilst only 30 $(13.5 \%)$ were normal. A number of criteria have been suggested for selection of patients for liver biopsy. The prothrombin time should be no more than 3 seconds prolonged, ${ }^{1}$ or less than $16 \cdot 7$ seconds (control 10.2-12.3); ${ }^{2}$ the platelet count at least $56 \times 10^{9} / 1^{2}$ or $80 \times$ $10^{9} / 1 ;^{1}$ and the haemoglobin concentration at least $89 \mathrm{~g} / 1 .{ }^{2}$ Imaging with ultrasound or CT before the procedure is recommended, ${ }^{1}$ so that the best and safest area for biopsy can be selected. However, ultrasound or CT-guidance of biopsies probably need only be routine in patients with focal lesions. ${ }^{6}$

McGill et $a l^{2}$ reported that the presence of malignancy, advanced age, female sex, and the number of passes with the biopsy needle were the only factors which predicted bleeding. Recently, however, major haemorrhage and death following liver biopsy have been recorded in five patients with AIDS. ${ }^{34}$ Four of these patients had no obvious risk factor for bleeding, whilst the fifth bled from previously unrecognised hepatic Kaposi's sarcoma. The high incidence of major bleeding we observed following liver biopsy may simply reflect the fact that three of our patients had clotting abnormalities and were thus at high risk of bleeding. Anaemia may also have contributed to the high mortality following haemorrhage from the biopsy site. However, it is also possible that HIV infection per se is associated with increased risk of bleeding following biopsy, perhaps due to unrecognised impairment of platelet function, undetected abnormalities of clotting, or ultrastructural abnormalities in the liver $^{3}$ which might impair mechanical compression of the needle tract, as even in the face of entirely normal platelet levels and clotting tests, fatal haemorrhage may still occur. ${ }^{3}$

Although liver biopsy may be very useful in the management of patients with HIV infection, ${ }^{7}$ most of the infections and tumours which may affect the liver are disseminated, 
and are present in other organs. Prego et al ${ }^{8}$ found that liver biopsy had a higher sensitivity and gave a more rapid result than blood culture or bone marrow biopsy in febrile HIVinfected patients with mycobacterial disease. Recently, however, Miralles et $a l^{9}$ reported that aspiration and biopsy of lymph nodes or bone marrow gave a higher diagnostic yield in HIV-infected patients with fever of unknown origin. The relative clinical utility of different investigations probably depends on the prevalence of different opportunistic infections such as tuberculosis and leishmaniasis in the community, and even if less invasive tests are performed initially, there will remain a group in whom liver biopsy is clearly indicated. ${ }^{7}$ Thrombocytopaenia, anaemia, and abnormalities of clotting tests are all common in patients with symptomatic HIV disease, both due to HIV infection itself and as a result of drug therapy. ${ }^{10}$ Nevertheless, it is essential that full correction of abnormalities is carried out before liver biopsy in patients with HIV infection, and if clotting abnormalities cannot be corrected, and it is deemed essential to perform a liver biopsy, transjugular or plugged percutaneous techniques should be used, depending on local expertise. With hindsight, these techniques would have been more appropriate than percutaneous needle biopsy in cases 1-3. In the light of our experience, early intervention with surgery or hepatic artery embolisation should be considered in patients with HIV infection who have significant bleeding after liver biopsy.

1 Sherlock S, Dooley J. Diseases of the Liver and Biliary System. 9th ed. Oxford: Blackwell Scientific Publications

2 McGill DB, Rakela J, Zinsmeister AR, Ott BJ. A 21-year experience with major haemorrhage after percutaneous liver biopsy. Gastroenterology 1990;99:1396-1400.

3 Gordon SC, Veneri RJ, McFadden RF, Reddy KR, Schiff ER. Major haemorrhage after percutaneous liver biopsy in patients with AIDS. Gastroenterology 1991;100:1787.

4 Gottesman D, Dyrszka H, Albarran J, Hilfer J. AIDSrelated hepatic Kaposi's sarcoma: massive bleeding following liver biopsy. Am 7 Gastroenterol 1993;88:762-4.

5 Wilkins MJ, Lindley R, Dourakis SP, Goldin RD. Surgical pathology of the liver in HIV infection. Histopathology pathology of the

6 Vautier G, Scott B, Jenkins D. Liver biopsy: guided or not? BMF 1994;309:1455-6.

7 Cavicchi M, Pialoux G, Carnot F et al. Value of liver biopsy for the rapid diagnosis of infection in human immunodeficiency virus-infected patients who have unexplained fever and elevated levels of alkaline phosphatase or $\gamma$ glutamyl transferase. Clin Inf Dis 1995;20:606-10.

8 Prego V, Glatt AE, Roy V, Thelmo W, Dinscoy $H$, Raufman JP. Comparative yield of blood culture for fungi and mycobacteria, liver biopsy and bone marrow biopsy in the diagnosis of fever of undetermined origin in human immunodeficiency virus-infected patients. Arch Intern Med 1990;150:333-6.

9 Miralles P, Moreno S, Perez-Tascon M, Cosin J, Diaz MD Bouza E. Fever of uncertain origin in patients infected with the human immunodeficiency virus. Clin Infect Dis 1995;20:872-5.

10 Doweiko JP. Management of the haematologic manifestations of HIV disease. Blood Reviews 1993;7:121-6. 